PF 2020 (75/1): 241-262

https://doi.org/10.32798/pf.659

\author{
VÁCLAVA KETTNEROVÁ \\ VERONIKA KOLÁŘOVÁ \\ Matematicko-fyzikální fakulta \\ Univerzita Karlova \\ Ústav formální a aplikované lingvistiky, Praha \\ e-mail: kettnerova@ufal.mff.cuni.cz \\ ORCID 0000-0001-9694-1304 \\ e-mail: kolarova@ufal.mff.cuni.cz \\ ORCID 0000-0001-5184-579X
}

\title{
VALENCE ČESKÝCH VERBÁLNÍCH JMEN V NOMINÁLNÍCH KONSTRUKCÍCH A VE VERBONOMINÁLNÍCH PREDIKÁTECH S KATEGORIÁLNIIM SLOVESEM ${ }^{1}$
}

\section{VALENCY OF CZECH VERBAL NOUNS IN NOMINAL CONSTRUCTIONS AND IN VERBONOMINAL CONSTRUCTIONS WITH LIGHT VERBS}

\begin{abstract}
Comparing valency behavior of the two selected types of Czech verbal nouns (ending in -ní/-tî), i.e. the ones denoting actions, e.g. poučení 'instructing', and the ones denoting abstract results of actions, e.g. poučení 'advice', it can be observed that they differ especially in the surface syntactic expression of their valency complementations. In nominal constructions, surface expression of valency complementations of verbal nouns denoting actions can be typically derived from valency structure of their base verbs. In contrast, verbal nouns denoting abstract results of actions often express their valency complementations on the surface in a non-systemic way. In verbonominal constructions, the syntactic center of which is a light verb, verbal nouns denoting actions systematically employ their participant Agent (in a broad sense) on the surface as the subject provided by the light verb. Contrary to that, verbal nouns denoting abstract results of actions can often express more

1 Tento př́spěvek vznikl za podpory projektu Grantové agentury ČR s názvem „Valence neslovesných predikátů“ (GA19-16633S) a projektu Ministerstva školství, mládeže a tělovýchovy ČR „Digitální výzkumná infrastruktura pro jazykové technologie, umění a humanitní vědy“ LINDAT/CLARIAH-CZ (LM2018101); tato studie využívá jazykové zdroje a nástroje vyvinuté, uchovávané a distribuované v rámci druhého uvedeného projektu.
\end{abstract}


semantic participants on the surface as verbal modifications, and the choice of light verbs can change the perspective from which the situations denoted by these verbal nouns are viewed.

KEYWORDS: stem nominals light verb constructions, actions, abstract results of actions KLÍČOVÁ SLOVA: kmenové deriváty verbonominální predikáty s kategoriálním slovesem, událost, abstraktní výsledek děje

SŁOWA KLUCZOWE: derywaty nominalne z konektywami werbo-nominalne predykaty z czasownikiem kategorialnym, zdarzenie, abstrakcyjny rezultat akcji

\section{1. Úvod}

Verbální jména, někdy označovaná jako substantiva na - $n(i) /-t(i)$, typicky vyjadřují události (1a) a (2a), avšak mohou označovat i abstraktní výsledek děje (2c), substanci (2e) nebo kvantitu, zejm. tzv. kontejnery $(1 \mathrm{c})^{2}$. Verbální jména prvních dvou významů tvoří jak nominální konstrukce, tak v některých případech konstrukce verbonominální, jejichž syntaktickým jádrem je kategoriální sloveso, srov. dvojice příkladů $(1 \mathrm{a}-\mathrm{b}) \mathrm{a}(2 \mathrm{c}-\mathrm{d})^{3}$. $\mathrm{V}$ tomto příspěvku se zaměříme právě na verbální jména označující události a abstraktní výsledky děje a budeme je zkoumat z hlediska uplatnění jejich valenční struktury v nominálních konstrukcích a ve verbonominálních konstrukcích s kategoriálním slovesem.

(1) a. balení dárků rodiči

b. Společnost provádí balení zboží do kontejnerů.

c. poloprázdné balení léků

(2) a. příležitost pro potěšení bližních živým dárkem

b. *využil příležitost provést/uskutečnit/vykonat potěšení svých bližních živým dárkem

c. jejich potěšení ze hry bylo dobře znát

d. Děti mají potěšení ze hry.

e. sladké potěšení jménem Fidorka

2 K základním sémantickým kategoriím patř́ dále např. vlastnost nebo okolnost, viz Čermák (2011, s. 227). Např. ve slovníku NomVallex I. (Kolářová et al. 2020), který obsahuje celkem 159 lexémů verbálních jmen zahrnujících celkem 322 lexikálních jednotek, vyjadřuje 253 jednotek (78,6 \%) událost, 51 jednotek $(15,8 \%)$ abstraktní výsledek děje, 11 jednotek $(3,4 \%)$ substanci a pouze 1 jednotka $(0,3 \%)$ označuje kontejner (zbývajících šest jednotek má spíše smíšené sémantické vlastnosti).

3 Radimský (2010, s. 137) zužuje okruh verbálních jmen vyskytujících se ve verbonominálních konstrukcích s tzv. generickými kategoriálními slovesy typu provádět ${ }^{\text {mpf }} /$ provés $^{t^{\mathrm{pf}}}$ na jména odvozená od akčních sloves, srov. prŕíklady (1a-b) s př́íklady (2a-b). 
U verbálních jmen se mezi kořenem a sufixem - $n(i) /-t(i)$ nachází kmenotvorný sufix nesoucí vidovou charakteristiku (viz např. sufix -á- ve jménu namít-á-n-ímpf a -nu- u jména namit-nu-t- $\mathfrak{p}^{\mathrm{p}}$; odtud též označení kmenové deriváty). Deverbální jména vyjadřující události nebo abstraktní výsledky děje však mohou být tvořena i dalšími sufixy, včetně sufixu nulového, které se připojují přímo ke kořeni slovesa (např. námit-ka, návrh-0; odtud též označení kořenové deriváty), a tato jména tak informaci o vidu nenesou. Na rozdíl od kmenových derivátů tato jména vyjadřují častěji abstraktní výsledky děje než události ${ }^{4}$. Zatímco jejich zapojení do konstrukcí s kategoriálním slovesem byla již věnována nemalá pozornost (Radimský 2010; Macháčková 1983; Kettnerová et al. 2018), výskyt verbálních jmen v konstrukcích s kategoriálním slovesem byl v uvedených pracích zkoumán spíše okrajově; Radimský (2010, s. 63-70) na korpusových datech např́klad dokládá, že v konstrukcích s kategoriálním slovesem převažují dokonavá verbální substantiva (konkrétně jména zakončená na -ení) nad nedokonavými (zakončenými na -ování). Verbonominální konstrukce s verbálními jmény však vyžadují detailnější zkoumání, a to zejména s ohledem na utváření jejich syntaktické struktury.

Problematiku valence verbálních substantiv zpracováváme v teoretickém rámci Funkčního generativního popisu (nadále FGP), viz Panevová (1980; 2002) a Panevová et al. (2014); opíráme se o korpusový materiál řady SYN Českého národního korpusu (Křen et al. 2019). Valenci zachycujeme v podobě valenčního rámce, jímž rozumíme zápis, v němž je pro každé valenční doplnění daného řídícího slova (v tomto př́padě substantiva nebo kategoriálního slovesa) vyhrazena právě jedna pozice; tato pozice je označená tzv. funktorem, vyjadřujícím syntakticko-sémantický vztah daného valenčního doplnění k řídícímu substantivu či kategoriálnímu slovesu. Ve valenčním rámci sloves je u každého doplnění vyznačena jeho obligatornost; u jmen obligatornost doplnění nebyla ověřována, proto ji nevyznačujeme. Počet, typ a př́padně obligatornost valenčních doplnění odrážejí hloubkověsyntaktické rysy sloves a jmen. Jejich povrchověsyntaktické vlastnosti jsou ve valenčních rámcích zachyceny pomocí morfematických forem, které popisují povrchové vyjádření valenčních doplnění. Do valenčních rámců zkoumaných sloves a substantiv zapisujeme aktanty Konatel (ACT), Patiens (PAT), Adresát (ADDR), Efekt (EFF) a Původ (ORIG), např. instruktorovo. ACT poučení řidiče. ADDR o bezpečnosti.PAT práce, poučeni se $z$ chyb.ORIG, kontrolování nabídek.PAT, zda splňují.EFF veškeré náležitosti, a dále obligatorní volná doplnění , např. směrové určení „odkud“(DIR1)

4 Např. ve slovníku NomVallex I., který obsahuje celkem 89 lexémů kořenových derivátů zahrnujících celkem 183 lexikálních jednotek, vyjadřuje 118 jednotek (64,5\%) abstraktní výsledek děje a pouze 8 jednotek $(4,4 \%)$ událost; $\mathrm{k}$ dalším významům kořenových derivátů viz Kolářová et al. (2020, s. 56).

Na rozdíl od aktantů, jejichž povrchové vyjádření je dáno rekcí, nejsou morfematické formy volných doplnění ve valenčních rámcích uváděny, jelikož je lze vyvodit ze sémantiky doplnění. 
$\mathrm{v}$ konstrukci vypovědět občana.PAT z území.DIR1 státu'. Slovesné valenční rámce uvedené v tomto článku vycházejí z valenčního slovníku VALLEX (Lopatková et al. 2016), substantivní valenční rámce ze slovníku NomVallex ${ }^{8}$ (Kolářová et al. 2020), jsou-li daná slovesa a jména ve slovnících obsažena.

\section{Valence verbálních substantiv v nominálních konstrukcích}

Valence verbálních substantiv je dána především tím, zda dané substantivum označuje událost (děj nebo stav), abstraktní výsledek děje, substanci nebo kvantitu (Dvořák 2016; Kolářová et al. 2020). Událost (odd. 2.1) a abstraktní výsledek děje (odd. 2.2) jsou velmi blízké významy, jejichž rozlišení u verbálních jmen nemusí být $\mathrm{v}$ některých kontextech jednoznačné; $\mathrm{v}$ hraničních případech se při jejich rozlišení ŕídíme charakteristickými morfosyntaktickými vlastnostmi (Kolářová et al. 2020, s. 76-88), které byly pro jména označující událost detailně popsány v pracích navazujících na transformačně-generativní gramatiku (např. Veselovská 2001; Dvořák 2016; Karlík 2019).

\subsection{Verbální jména označující událost}

Označují-li verbální jména událost, uchovávají si některé verbální morfosyntaktické vlastnosti, zejména vyjadřují vid (např. poučováni $\imath^{\text {mpf }} /$ poučeníp ${ }^{\mathrm{f}}$ ridiče o bezpečnosti práce). Součástí jejich lemmatu může být - stejně jako u sloves - klitické reflexivum se nebo si (např. poučování se $e^{\mathrm{impf}} / p o u c ̌ e n i ́ ~ s e^{\mathrm{pf}} z$ chyb, presvědčování

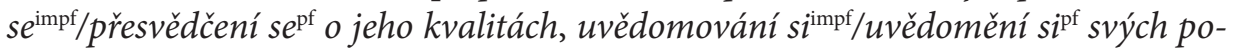
vinnostî $)^{9}$. O slovesném charakteru verbálních jmen daného typu svědčí i jejich syntaktické chování: tato jména totiž se svými základovými slovesy sdílejí hloubkovou syntaktickou strukturu, tedy vyznačují se stejným počtem valenčních doplnění a stejnými funktory, srov. valenční rámec slovesa poučovat ${ }^{\mathrm{impf}} /$ poučit $^{\mathrm{pf}}$ (3a) a valenční rámec verbálního substantiva poučováni impf / poučeni $i^{\mathrm{pf}}(3 \mathrm{~b})^{10}$. Mění se pouze adnominální morfematické formy některých valenčních doplnění, tedy povrchové vyjádření zasažených doplnění. Změny těchto forem jsou převážně systémové: tyto adnominální formy mají původ ve formách odpovídajících valenčních doplnění základových sloves př́slušných substantiv, a lze je tak na

$6 \quad$ U kvantitativních substantiv přichází v úvahu též aktant Material (MAT), např. balení léků.MAT, viz výše př́klad (1c).

7 http://ufal.mff.cuni.cz/vallex/3.5/

8 https://ufal.mff.cuni.cz/nomvallex

9 Viz napr. Veselovská 2001, s. 23.

10 Vidové protějšky tvořené sufixálně sdílejí valenční strukturu, proto jsou ve slovnících VALLEX i NomVallex zpracovány v rámci jediného lexému, a to jak u sloves, např. poučovat ${ }^{\text {mpff }}$ /

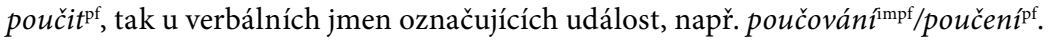


základě formálních pravidel $\mathrm{z}$ těchto forem odvodit. K typickým systémovým změnám patři změna nominativní a akuzativní vazby ve vazbu genitivní nebo posesivní v (4a-c), u substantiv odvozených od tranzitivních sloves př́ípadně změna nominativní vazby ve vazbu instrumentálovou v (4c). Ostatní morfematické formy (zejména bezpředložkový genitiv, dativ a instrumentál, předložkové pády, infinitiv a vedlejší věta) zůstávají zpravidla beze změny, srov. předložkovou skupinu o+lokál v (4a-c), blíže viz Kolářová et al. (2020).

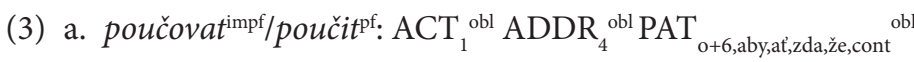

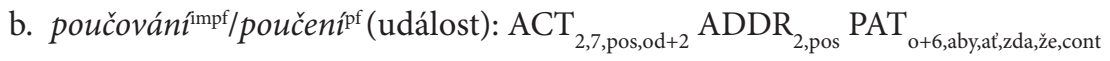

(4) a. instruktor ${ }_{A C T-\text { nom }}$ poučoval/poučil řidiče ${ }_{\text {ADDR-acc }}$ o bezpečnosti PAT-o+loc $_{\text {práce }}$

b. instruktorovo ${ }_{\text {ACT-pos }}$ poučování/poučení řidiče ${ }_{\text {ADDR-gen }}$ o bezpečnosti ${ }_{\text {PAT-o+loc }}$ práce

c. řidičovo ${ }_{\mathrm{ADDR} \text {-pos }}$ poučování/poučení instruktorem ${ }_{\mathrm{ACT} \text {-instr }}$ o bezpečnosti ${ }_{\mathrm{PAT}-\mathrm{oH}+\mathrm{loc}}$ práce

\subsection{Verbální jména označující abstraktní výsledek děje}

Při označení abstraktního výsledku děje verbální jména postrádají typicky verbální morfosyntaktické vlastnosti. Ztrácejí vidový význam (jejich morfologický vztah k perfektivnímu nebo imperfektivnímu základovému slovesu je pouze formální, srov. něči náboženské přesvědčení odvozené od perfektivního slovesa). Oproti verbálním jménům ve významu události, která bývají obvykle odvozena od obou vidových protějšků př́slušných základových sloves, nap̌r. poučováni mpf/ poučenip ${ }^{\mathrm{f}}$ ridiče o bezpečnosti práce, se derivátem označujícím abstraktní výsledek děje stává většinou pouze jeden člen vidové dvojice, a to výrazně častěji substantivum odvozené od perfektivního slovesa, srov. poučen $i^{\mathrm{p}}$ ř́idiči vs. ${ }^{\star}$ poučováni $i^{\text {mpf }}$

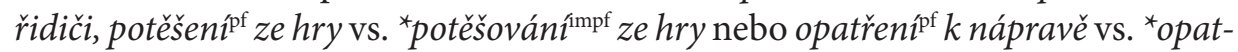
rovánímpi $k$ nápravě. Substantivum odvozené od imperfektiva nabývá významu abstraktního výsledku děje jen okrajově, srov. abstraktní výsledek děje cítění pro estetiku vs. událost cítění určité vưně. Vzhledem ke ztrátě dějového významu dále nemůže být součástí lemmatu substantiv daného typu klitické reflexivum se nebo si, např̀. ${ }^{*}$ něči náboženské presvědčení se, ${ }^{*}$ něčí národní uvědomèní si.

Substantiva označující abstraktní výsledek děje si uchovávají slovesný charakter valenčních doplnění, většinou zachovávají i jejich počet, srov. valenční rámec substantiva poučení s významem abstraktního výsledku děje v (5) s rámcem základového slovesa v (3a) výše. Avšak u některých substantiv tohoto významu dochází ke změně počtu valenčních doplnění, srov. valenční rámce substantiva pomyšlení ve významu události $\mathrm{v}(7 \mathrm{~b})$ a ve významu abstraktního výsledku děje $\mathrm{v}(7 \mathrm{c})$, exemplifikované po řadě príklady $(7 \mathrm{~d}) \mathrm{a}(7 \mathrm{e}), \mathrm{s}$ rámcem jejich základového slovesa $\mathrm{v}(7 \mathrm{a})$. $\mathrm{V}$ př́padě substantiv vyjadřujících abstraktní výsledek děje tak 
- oproti těm, která mají význam události - pozorujeme i možné změny v hloubkové struktuře.

$\mathrm{Na}$ rozdíl od jmen označujících událost využívají substantiva označující abstraktní výsledky děje pro povrchové vyjádření svých valenčních doplnění vedle systémových forem i formy nesystémové, které nemají oporu ve valenci zákla-

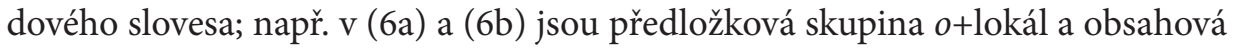
věta pro vyjádření PAT spolu s genitivním vyjádřením ACT systémovými formami, zatímco dativní a předložkové vyjádření ADDR jsou formami nesystémovými, jelikož nemají oporu ve formách ADDR základového slovesa, srov. výše adverbální akuzativní formu ADDR v $(3 \mathrm{a})^{11}$.

(5) poučení (abstraktní výsledek děje): $\mathrm{ACT}_{2, \mathrm{pos}, \mathrm{od}+2} \mathrm{ADDR}_{3, \mathrm{pro}+4}$ $\mathrm{PAT}_{\text {o+6,inf,aby,at,zda, že,cont }}$

(6) a. neobsahuje poučení řidiči ${ }_{\text {ADDR-dat }}$ o bezpečnosti $i_{\text {PAT-o+loc }}$ práce

b. jako poučení zkušeného hráče ${ }_{\text {ACT-gen }}$ pro devatenáctiletého kluka ${ }_{\text {ADDR-pro+acc' }}$ at'si na takové věci dá ${ }_{\mathrm{PAT}-\mathrm{at}}$ pozor (SYNv8)

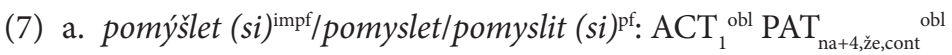

b. pomýšlenímpf $/$ pomyšleni $i^{\mathrm{pf}}$ (událost): $\mathrm{ACT}_{2, \mathrm{pos}} \mathrm{PAT}_{\text {na+4,̌̌e,cont }}$

c. pomyšlení (abstraktní výsledek děje): $\mathrm{ACT}_{2, \text { pos }}$

d. jeho ${ }_{\text {ACT-pos }}$ pomyšlení na to, co bude ${ }_{\text {PAT-cont }}$ dál

e. je to nad naše ${ }_{\text {ACT-pos }}$ pomyšlení (přání, představa)

\section{Valence verbálních jmen ve verbonominálních konstrukcích s kategoriálním slovesem}

Kromě nominálních konstrukcí, diskutovaných v odd. 2, vytvářejí verbální jména označující události a abstraktní výsledky děje i konstrukce s kategoriálními slovesy. $\mathrm{V}$ takovém př́padě verbální jméno selektuje určité sloveso a vytváří s ním víceslovnou lexikální jednotku, kterou nadále označujeme jako verbonominální predikát $\mathrm{s}$ kategoriálním slovesem ${ }^{12}$. Sémantickým jádrem těchto predikátů je verbální jméno, které se stává přímým či nepřímým objektem nebo

11 Nesystémové formy valenčních doplnění u jmen označujících abstraktní výsledky děje byly v NomVallexu I. doloženy u substantiv ze sémantických tř́d Communication (např. poučení řidiči), Mental Action (např. citění pro estetiku) a Psych State (např. potěšení ze hry), avšak ukázalo se, že nejsou vyloučené ani u dalších sémantických tříd, jako je Contact (např. Hudba jako pohlazení budoucím maminkám) nebo Providing (např. opatření k nápravě), k tomu viz Kolářová et al. (2020, s. 95).

12 Ve FGP se užívá též označení komplexní predikát, jelikož sémantickým jádrem těchto predikátů nemusí být jen jméno (např. dát najevo, vzít zpět). Vzhledem k zúžení jazykového materiálu na verbální jména zde budeme nadále využívat označení verbonominální predikát a verbonominální 
subjektem jím selektovaného kategoriálního slovesa. Kategoriální slovesa jsou ve verbonominálních predikátech s verbálními jmény do vysoké míry sémanticky vyprázdněná, a lze je tak obvykle vypouštět tzv. redukčním testem, viz Radimský (2010). Sémantický status kategoriálních sloves je ovšem předmětem živých debat: jedni tato slovesa považují za sémanticky vyprázdněná (Jespersen 1965; Gross 1981; Cattell 1984; Grimshaw, Mester 1988), zatímco druzí jim určitou sémantickou roli připisují (Butt 2010; Apresjan 2009; Bosque 2001; Jezek 2011); podstatnou roli zde často sehrává především vymezení sémantiky a hloubkové syntaxe v teoretických rámcích, z nichž autoři vycházejí. Ze syntaktického hlediska kategoriální sloveso $\mathrm{v}$ rámci verbonominálních predikátů poskytuje svou valenční strukturu, skrz niž se v povrchové struktuře věty uplatňují některé ze sémantických participantů verbálního jména ${ }^{13}$.

Základní definice verbonominálních predikátů s kategoriálním slovesem $\mathrm{v}$ rámci FGP byla zpracována na základě predikátů, u nichž jméno obsazuje pozici přímého objektu slovesa, viz Kettnerová et al. $(2018)^{14}$. Tato definice počítá $s$ rozlišením jednotek tří různých plánů: sémantických participantů (jako jednotek sémantického plánu), valenčních doplnění (jako jednotek hloubkové syntaxe) a větných členů (jako jednotek povrchové syntaxe) ${ }^{15}$. Tuto definici mírně modifikujeme tak, aby vyhovovala i verbonominálním predikátům, u nichž jméno obsazuje i jinou povrchovou pozici nežli př́mý objekt. Za verbonominální predikáty s kategoriálním slovesem zde považujeme takové souvýskyty slovesa a jména, které splňují následující podmínky:

- jméno je valenčním doplněním slovesa,

- sloveso nemá sémantické participanty ${ }^{16}$,

konstrukce s kategoriálním slovesem, viz též Radimský (2010). V české jazykovědě se dále užívá také termín analytický predikát (Macháčková 1979; Daneš et al. 1987; Radimský 2017).

13 Povahovodějové vlastnosti verbonominálních predikátů zde necháváme stranou. Upozorněme zde pouze, že ve verbonominálních predikátech s verbálními jmény označujícími událost dochází ke spojení dvou vidových charakteristik, a to vidové hodnoty kategoriálního slovesa

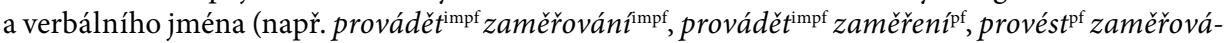
$n i^{\text {impf }}$, provés $\left.\mathrm{t}^{\mathrm{f}} z a m e ̌ r e n i^{\mathrm{ff}}\right)$. V prŕṕpadě verbonominálních predikátů, u nichž verbální jméno vyjadřuje abstraktní výsledek děje, k takovému spojení nedochází, jelikož je v nich nositelem vidu pouze kategoriální sloveso (např. dostávat ${ }^{\mathrm{impf}} /$ dostat $^{\mathrm{pf}}$ ocenění/ ${ }^{*}$ oceňování, učinit ${ }^{\mathrm{pf}}$ opatření/*opatřování). Viz odd. 2.

14 Mimo rámec FGP byla problematika syntaktického chování verbonominálních predikátů v češtině nejdetailněji popsána Macháčkovou (1979; 1983) a nověji Radimským (2010).

15 Zatímco inventář valenčních doplnění a větných členů je v rámci FGP stanoven, sémantické participanty, které odrážejí lexikálněsémantické rysy a které nemají oporu v jazykově strukturovaném významu, dosud vymezeny nebyly. Zde je popisujeme pomocí sémantických rolí, které čerpáme ze zdroje CzeEngClass lexicon (Urešová et al. 2019).

16 Skutečnost, že kategoriálním slovesům nepřipisujeme sémantické participanty, je v souladu s pozorováním, že daná slovesa mají pouze jazykově strukturovanou část významu (odpovídající 
- má-li sloveso další valenční doplnění, jsou tato doplnění sémanticky saturována sémantickými participanty jména skrz koreferenci s valenčními doplněními jména,

- ty sémantické participanty jména, které sémanticky saturují obligatorní valenční doplnění slovesa, jsou povrchověsyntakticky strukturovány v povrchových pozicích slovesa; ty, které saturují fakultativní valenční doplnění slovesa, mohou být strukturovány bud'v pozicích slovesa, nebo jména.

Jak pro verbální jména s významem události, tak pro verbální jména s významem abstraktního výsledku děje platí, že zatímco jejich hloubkověsyntaktická struktura je v rámci verbonominálních predikátů totožná s jejich hloubkovou syntaktickou strukturou v nominálních konstrukcích, jejich povrchověsyntaktická struktura se liší. Např. hloubkověsyntaktickou strukturu verbonominálního predikátu provést vytažení tvoří valenční doplnění obsažená ve valenčním rámci verbálního jména vytažení (8a), ACT, PAT a DIR1, sémanticky specifikovaná po řadě jako Agent, Theme a Source, a dále doplnění z valenčního rámce kategoriálního slovesa provést (8b), tedy sémanticky nespecifikovaný ACT a valenční doplnění rezervované pro verbální jméno, které je v souladu s FGP vyznačeno funktorem CPHR (Compound PHRaseme). Počet a typ valenčních doplnění verbálního jména vytažení je v rámci verbonominální konstrukce stejný jako v rámci nominální konstrukce, srov. zjednodušenou hloubkověsyntaktickou strukturu verbonominální konstrukce (9a), zachycenou na obr. 1a, s nominální konstrukcí (9b), zachycenou na obr. 1 b.

(8) a. vytahovánímpf /vytaženíp ${ }^{\mathrm{p}:} \mathrm{ACT}_{2,7, \mathrm{pos}} \mathrm{PAT}_{2, \mathrm{pos}} \mathrm{DIR} 1$

b. provádět $t^{\mathrm{impf}} /$ provést $^{\mathrm{pf}}: \mathrm{ACT}_{1}{ }^{\text {obl }} \mathrm{CPHR}_{4}{ }^{\text {obl }}$

(9) a. Jednotka ${ }_{\text {ACT-v-nom }}$ provedla vytažení ${ }_{\text {CPHR-v-acc }}$ utonulé osoby PAT-n-gen $_{\text {n }}$ z rybníka ${ }_{\text {DIR1-n-z+gen }}$ na žádost policie. $\left(\right.$ SYN2015) ${ }^{17}$

b. vytažení utonulé osoby $y_{\text {PAT-n-gen }}$ z rybníka $_{\text {DIR1-n-z+gen }}$ jednotkou ${ }_{\text {ACT-n-instr }}$

hloubkověsyntaktickým rysům), nikoli individuální lexikálněsémantické rysy, srov. též Alonso Ramos (2007). Jedinou výjimku, kdy je kategoriální sloveso vybaveno sémantickým participantem, představují kategoriální slovesa s kauzativním významem, u nichž je jedno $\mathrm{z}$ valenčních doplnění sémanticky specifikováno jako Kauzátor (napr. Konatel slovesa dávat ve větě s verbonominálním predikátem dávat naději: Slibná forma ${ }_{\mathrm{ACT}}$ dává Šromové naději na US Open ... (SYNv4)); případná další valenční doplnění těchto sloves ovšem zůstávají sémanticky nespecifikovaná. Tyto př́ípady zde necháváme stranou.

17 Indexy v a n rozlišují mezi verbálními a nominálními doplněními. 


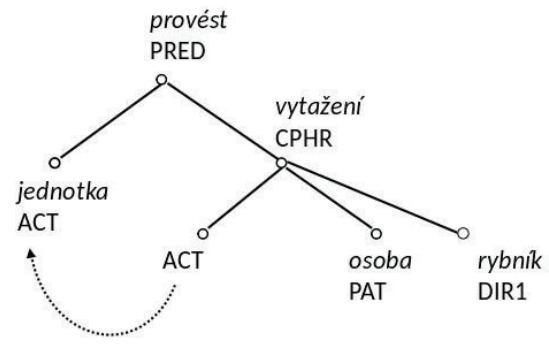

a.

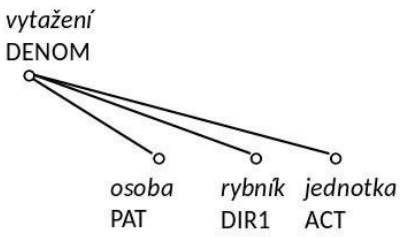

b.

Obrázek 1. Zjednodušený závislostní strom verbonominální konstrukce (9a) (strom a. vlevo) a nominální konstrukce (9b) (strom b. vpravo); koreference verbálních a nominálních valenčních doplnění je vyznačena šipkou směřující od povrchově nevyjádřeného valenčního doplnění $\mathrm{k}$ doplnění povrchově vyjádřenému

Ta valenční doplnění jména, která skrz koreferenci sémanticky saturují valenční doplnění kategoriálního slovesa, typicky podléhají systematickému povrchovému vypuštění. Elipsa těchto doplnění jména $\mathrm{v}$ důsledku vede $\mathrm{k}$ tomu, že každý sémantický participant daný jménem je v povrchové struktuře verbonominálního predikátu s kategoriálním slovesem realizován právě jednou, stejně jako je tomu v syntaktických strukturách predikativních sloves ${ }^{18}$. Shrňme zde principy utváření povrchověsyntaktické struktury verbonominálních predikátů s kategoriálním slovesem, odrážející v některých bodech výše uvedené definiční vlastnosti daných konstrukcí (Kettnerová et al. 2018):

1. verbální jméno je vyjádřeno v jedné z povrchověsyntaktických pozic kategoriálního slovesa;

2. ty sémantické participanty verbálního jména, které skrze koreferenci sémanticky saturují valenční doplnění slovesa, jsou vyjádřeny v závislosti na obligatornosti slovesného doplnění:

2.1. je-li dané slovesné doplnění obligatorní, pak je sémantický participant jména na povrchu vyjádřen v povrchověsyntaktické pozici dané prŕíslušným valenčním doplněním slovesa;

2.2. je-li dané slovesné doplnění fakultativní, pak je sémantický participant jména na povrchu vyjádřen bud' v povrchověsyntaktické pozici dané valenčním doplněním slovesa, nebo $\mathrm{v}$ povrchověsyntaktické pozici dané valenčním doplněním jména;

3. ty sémantické participanty jména, které korespondují pouze s valenčními doplněními jména, jsou vyjádřeny $\mathrm{v}$ príslušných povrchověsyntaktických pozicích jména.

18 Ř́dké výjimky, kdy je na povrchu vyjádřen jak ACT slovesa, tak ACT jména, zde necháváme stranou (např. Petr ACT-v $_{m} m u$ dal svưj ${ }_{\mathrm{ACT}-\mathrm{n}}$ slib). 
Např. v rámci verbonominálního predikátu provést vytažení je verbální jméno vytažení vyjádřeno jako objekt slovesa provést (princip 1 výše). Toto verbální jméno charakterizují tř̌i sémantické participanty Agent, Theme a Source, které jak v nominálních, tak ve verbonominálních konstrukcích s kategoriálním slovesem korespondují se jmenným ACT, PAT a DIR1. V rámci verbonominálního predikátu provést vytažení sémanticky nespecifikovaný ACT kategoriálního slovesa provést koreferuje s ACT jména, a získává tak skrz koreferenci totožnou sémantickou specifikaci: jak jmenný ACT, tak slovesný ACT odkazují k participantu Agent. Jelikož je ACT kategoriálního slovesa obligatorní, Agent se na povrchu realizuje nominativem, tedy v subjektu (viz princip 2.1 výše), jak je pro ACT slovesa určeno ve valenčním rámci slovesa provést (8b), viz povrchová struktura věty (9a) výše. Theme a Source, jako participanty, které korespondují pouze s valenčními doplněními jména, jsou na povrchu vyjádřeny jako adnominální atributy (princip 3 výše), jak určují ve valenčním rámci jména morfematické formy pro doplnění PAT a DIR1, viz valenční rámec $(8 \mathrm{a})$ a realizace těchto doplnění v př́kladu $(9 \mathrm{a})^{19}$.

Verbonominální predikáty, u nichž je verbální jméno vyjádřeno v objektových pozicích (odd. 3.1), se v povrchovém elidování valenčních doplnění jména systematicky liší od predikátů, v nichž verbální jméno obsazuje subjektovou pozici (odd. 3.2). Tyto rozdíly vyplývají z podoby valenčních rámců kategoriálních sloves selektovaných verbálními jmény.

\subsection{Verbální jména v objektových pozicích}

\subsubsection{Význam události}

Verbální jména s významem události se v pozici přímého objektu objevují zejména u kategoriálních sloves činit ${ }^{\mathrm{impf}}$, dělat ${ }^{\mathrm{imp}}$, konat ${ }^{\mathrm{impf}}$, podnikat ${ }^{\mathrm{impf}} /$ podniknout $^{\mathrm{pf}}$, provádět ${ }^{\mathrm{t} \mathrm{mp}} /$ provést $^{\mathrm{pf}}$, provozovat ${ }^{\mathrm{impf}}$, učinit $^{\mathrm{pf}}$, udělat ${ }^{\mathrm{pf}}$, uskutečňovat $^{\mathrm{impf}} /$ uskutečnit $^{\mathrm{pf}}$, vykonávat ${ }^{\mathrm{imp} /} / v k_{k o n a t^{\mathrm{p}}{ }^{20}}{ }^{20}$ ř́kladem kategoriálního slovesa, u nějž se verbální

19 Princip 2.2 demonstrujeme v oddíle 3.1.2.

20 Radimský (2010) uvádí obdobný seznam sloves, která se pojí se jmény s procesuálním významem, zde označovanými jako jména ve významu události. Korpusová sonda však ukazuje, že míra souvýskytu daných sloves s uvedenými jmény je různá. V korpusu SYN2015 jsme na základě dotazu [lemma=“..."\&tag="VV.*“], na jehož výsledek byl uplatněn pozitivní filtr $0,+1$ [tag="N...4.*“\&lemma=".*ní|ti'], vyhledaly v nejbližším pravém kontextu sloves jméno končící na -ní/-tí. Následná manuální analýza získaných výskytů slovesa a jmen ukázala, že nejvyšší míru souvýskytu jmen s významem události vykazují kategoriální slovesa provádět ( 97 \% výskytů; např. provádèt dobijení, střídání, testovánî) a provést (téměř $91 \%$; např. provést ohledání, zajištění, zateplenî), nejmenši provozovat ( $0,4 \%$; např. provozovat chlazení) a vykonávat $(0,1 \%$; např. vykonávat sčitání). Nižší míra souvýskytu sloves s verbálními jmény daného významu svědčí pro to, že sloveso má též predikativní funkce (např. provozovat zařizení, vykonávat nařízení, opatření). 
jméno označující událost vyskytuje v nepř́mém objektu, je sloveso věnovat $s e^{\text {impf }}$. Tato slovesa mají ve svém valenčním rámci kromě valenční pozice CPHR, rezervované pro verbální jméno vyjádřené bezpředložkovým akuzativem nebo dativem, nominativního Konatele (ACT). ACT jako sémanticky nesaturované valenční doplnění kategoriálního slovesa získává svou sémantickou specifikaci až $\mathrm{v}$ rámci verbonominálního predikátu skrz koreferenci s některým $\mathrm{z}$ valenčních doplnění verbálního jména. $V$ př́padě těchto predikátů pozorujeme systematickou koreferenci verbálního ACT se jmenným ACT. Např. selektuje-li verbální jméno s významem události doznání (se) kategoriální sloveso učinit, pak sémanticky nespecifikovaný ACT slovesa vstupuje do koreference s ACT jména, viz valenční rámce jména $\mathrm{v}(10 \mathrm{a})$ a slovesa $\mathrm{v}(10 \mathrm{~b})$. Protože ACT kategoriálního slovesa představuje obligatorní valenční doplnění, je z koreferující dvojice slovesný ACT a nominální ACT na povrchu vyjádřen právě slovesný ACT (princip 2.1, odd. 3), zatímco ACT verbálního jména je z povrchu vypuštěn, viz verbonominální konstrukce (11a); srov. též s nominální konstrukcí (11b).

Povrchověsyntaktické vyjádření participantu korespondujícího se jmenným ACT v pozici subjektu, dané Konatelem kategoriálního slovesa, je charakteristické pro verbonominální predikáty, $\mathrm{v}$ nichž pozici př́mého nebo nepř́mého objektu slovesa obsazuje verbální jméno s významem události; viz př́ílady (11a) a (9a) výše, dokládající verbální jméno daného typu v pozici přímého objektu, a dále př́klad (13a), v němž jméno obsazuje nepř́mý objekt; $k$ tomuto př́kladu dále viz též valenční rámec jména (12a) a slovesa (12b) a nominální konstrukci (13b).

(10) a. doznávání (se) impf/doznání (se)pf (událost): $\mathrm{ACT}_{2, \mathrm{pos}} \mathrm{ADDR}_{3} \mathrm{PAT}_{\mathrm{k}+3, \text { zdažě,cont }}$ b. učinit ${ }^{\mathrm{pf}}: \mathrm{ACT}_{1}^{\text {obl }} \mathrm{CPHR}_{4}^{\text {obl }}$

(11) a. Bývalý manžel ${ }_{\text {ACT-v-nom }}$ Hardingové nakonec učinil doznání ${ }_{\text {CPHR-v-acc }}$ že šlo ${ }_{\text {PAT-n-že }}$ o připravené spiknutí. (SYN2006pub)

b. doznání bývalého manžela $a_{A C T-n-g e n}$ Hardingové, že šlo $o_{\text {PAT-n-že }}$ o připravené spiknutí, všechny překvapilo

(12) a. vystavováni impf $/$ vystaveníp $\mathrm{p}^{\mathrm{f}}: \mathrm{ACT}_{2,7, \mathrm{pos}} \mathrm{PAT}_{2, \mathrm{pos}}$

b. věnovat se $e^{\text {impf: }} \mathrm{ACT}_{1}^{\text {obl }} \mathrm{CPHR}_{3}^{\text {obl }}$

(13) a. Klub ${ }_{\text {ACT-v-nom }}$ se už tehdy věnoval vystavování ${ }_{\text {CPHR-v-dat }}$ aut $_{\text {PAT-n-gen }}$ (SYN2015)

b. vystavování aut ${ }_{\mathrm{PAT}-\mathrm{n} \text {-gen }} \mathrm{klubem}_{\mathrm{ACT} \text {-n-nstr }}$ 


\subsubsection{Význam abstraktního výsledku děje}

Verbální jména vyjadřující abstraktní výsledek děje selektují širší okruh kategoriálních sloves, typických zejména pro spojení s kořenovými deriváty v daném význa-

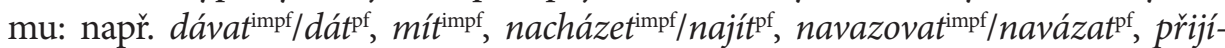

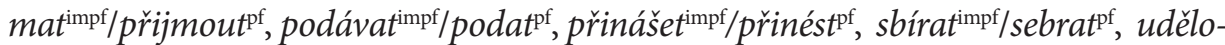
$v a t^{\text {impf}} / u d i l e t^{\text {impf }} / u d e ̌ l i t^{\mathrm{pf}}, v z n a ́ s ̌ e t^{\mathrm{impf}} / v z n e ́ s t^{\mathrm{pf}}$. Vzhledem $\mathrm{k}$ tomu, že valenční rámce mnohých z těchto sloves nejsou omezeny jen na CPHR a nominativního ACT, jako je tomu $\mathrm{v}$ př́padě sloves selektovaných jmény s významem událost (odd. 3.1.1), disponují jména označující abstraktní výsledek děje variabilnějšími možnostmi uplatnění svých sémantických participantů v povrchových pozicích slovesa ${ }^{21}$.

Srovnejme napřr. realizaci sémantických participantů jména poučení ve významu události v rámci verbonominálního predikátu provést poučení a téhož jména ve významu abstraktního výsledku děje, které se nachází např. v rámci verbonominálního predikátu dát poučení nebo dostat poučení. V obou př́padech je jméno poučení charakterizováno sémantickými participanty Teacher, Student a Fact, které po řadě korespondují s $\mathrm{ACT}$, $\mathrm{ADDR}$ a PAT jména, viz valenční rámce jmen $\mathrm{v}(14 \mathrm{a}) \mathrm{a}(14 \mathrm{~b})$. Dané významy jména se liší pouze povrchovým vyjádřením některých valenčních doplnění (instrumentálem u ACT jména ve významu události a formami ADDR), viz nominální konstrukce jména poučení ve významu události v (15a) a ve významu abstraktního výsledku děje v (15b).

Selektuje-li jméno poučení ve významu události kategoriální sloveso provést, sémanticky nesaturovaný ACT slovesa, viz valenční rámec slovesa $(8 \mathrm{~b})$ výše, vstupuje do koreference se jmenným ACT; z této dvojice koreferujících doplnění se na povrchu uplatňuje slovesný ACT jako obligatorní doplnění slovesa (princip 2.1, odd. 3). Participant Teacher, ke kterému dvojice koreferujících Konatelů referuje, je tak vyjádřen ve verbonominální konstrukci daného predikátu jako subjekt, jak určuje nominativ pro ACT ve valenčním rámci slovesa, viz př́iklad (15c). Ostatní participanty jména - Student a Fact - jsou ve verbonominální konstrukci povrchově vyjádřeny jako adnominální atributy, jak stanoví morfematické formy pro ADDR a PAT rámec jména (14a), viz př́klad (15c) a obr. 2a.

Verbální jméno poučení ve významu abstraktního výsledku děje selektuje např. kategoriální slovesa dát a dostat. Obě slovesa disponují ve valenčním rámci kromě nominativního ACT a akuzativního CPHR dalším valenčním doplněním: sloveso dát dativním ADDR, viz valenční rámec (14c), a sloveso dostat doplněním ORIG, vyjádřeným předložkovou skupinou $o d / z+$ genitiv, viz rámec (14d). V rámci verbonominálního

21 Při anotaci velkého množství verbonominálních predikátů, u nichž predikativní jméno obsazuje pozici př́mého objektu, byla zjištěna koreference maximálně dvou párů valenčních doplnění jména a slovesa; $\mathrm{z}$ uvedeného zjištění vyplývá, že jako doplnění slovesa mohou být $\mathrm{v}$ rámci verbonominálních predikátů na povrchu uplatněny maximálně dva sémantické participanty jména (Kettnerová et al. 2018). 
predikátu dát poučení koreferuje sémanticky nenaplněný ACT slovesa s ACT jména (stejně jako v př́padě predikátu provést poučení, viz výše) a navíc ADDR slovesa s ADDR jména; první dvojice odkazuje k participantu Teacher a druhá k participantu Student. Jelikož je jak ACT, tak ADDR kategoriálního slovesa obligatorní, vyjadřují se oba sémantické participanty $\mathrm{v}$ povrchověsyntaktických pozicích slovesa (princip 2.1, odd. 3), a to po řadě jako subjekt a neprrímý objekt, viz příklad (15d) a obr. $2 \mathrm{~b}$.

Ve verbonominálním predikátu dostat poučení dochází ke koreferenci ACT slovesa s ADDR jména (oba referují k participantu Student) a zároveň ke koreferenci ORIG slovesa a ACT jména (oba referují k participantu Teacher). Z první koreferující dvojice se na povrchu realizuje ACT slovesa, jelikož jde o obligatorní doplnění kategoriálního slovesa (princip 2.1, odd. 3). Participant Student je tak vyjádřen jako subjekt, jak určují formy pro ACT v rámci kategoriálního slovesa dostat (14d). Z druhé dvojice se vzhledem $k$ tomu, že ORIG slovesa je fakultativním doplněním, může vyjádřit v povrchové struktuře bud’ tento ORIG, nebo ACT jména (princip 2.2, odd. 3). Participant Teacher, ke kterému daná dvojice koreferujících doplnění odkazuje, tak může být na povrchu vyjádřen bud' jako nepř́mý objekt, jak morfematické formy určují pro ORIG ve valenčním rámci slovesa (14d), nebo jako adnominální atribut ve formách předepsaných pro nominální ACT v rámci jména (14b), srov. př́klad se slovesným ORIG v (15e), reprezentovaný na obr. 2c, a př́klad se jmenným ACT v (15f).

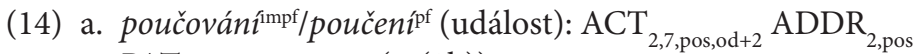
PAT $_{\text {o+6,aby,ä,zdaže,cont }}(=(3 \mathrm{~b}))$

b. poučení (abstraktní výsledek děje): $\mathrm{ACT}_{2, \mathrm{pos}, 0 \mathrm{~d}+2} \mathrm{ADDR}_{3, \text { pro+4 }}$

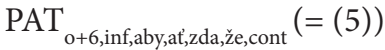

c. dávat ${ }^{\text {timf }} /$ dát $^{\mathrm{p}}: \mathrm{ACT}_{1}{ }^{\text {obl }} \mathrm{ADDR}_{3}{ }^{\text {obl }} \mathrm{CPHR}_{4}{ }^{\text {obl }}$

d. dostávat ${ }^{\mathrm{mpf}} /$ dostat $^{\mathrm{p}}: \mathrm{ACT}_{1}{ }^{\text {obl }} \mathrm{CPHR}_{4}{ }^{\text {obl }} \mathrm{ORIG}_{\text {od }+2,2+2}{ }^{\text {opt }}$

(15) a. poučení žáků ${ }_{A D D R-n-g e n}$ o nařízeních ${ }_{\text {PAT-n-otloc }}$ ve školním řádu učiteli ${ }_{A C T-n-n n s t r}$

b. instruktorovo ${ }_{\mathrm{ACT}-\mathrm{n} \text {-pos }}$ poučení zájemci ${ }_{\mathrm{ADDR} \text {-n-dat }}$ jak má přelézt ${ }_{\mathrm{PAT} \text {-n-cont }}$ zábradlí

c. Proto ihned v pondělí po pátečním incidentu prý učitelé ACT-v-nom $_{\text {všech }}$ trrídách provedli poučení ${ }_{\text {CPHR-v-acc }}$ žákủ $_{\text {ADDR-n-gen }}$ o nařízeních ${ }_{\text {PAT-n-o+loc }}$ ve školním řádu. (SYN2013pub)

d. Před skokem na pružném laně dá instruktor ${ }_{\text {ACT-v-nom }}$ zájemci $_{\text {ADDR-v-dat }}$ poučení $_{\text {CPHR-v-acc }}$ jak má přelézt ${ }_{\text {PAT-n-cont }}$ zábradlí.

e. Před skokem na pružném laně dostane zájemce ${ }_{\text {ACT-v-nom }}$ od instruktora ${ }_{\text {ORIG-v-od+gen }}$ poučení $_{\text {CPHR-v-acc }}$ jak má přelézt ${ }_{\text {PAT-n-cont }}$ zábradlí. (SYN2009pub)

f. Před skokem na pružném laně dostane zájemce ${ }_{\text {ACT-v-nom }}$ instruktorovo $_{\text {ACT-n-pos }}$ poučení, jak má ${ }_{\text {PAT-n-cont }}$ přelézt zábradlí. 


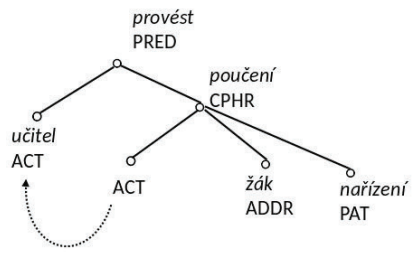

a.

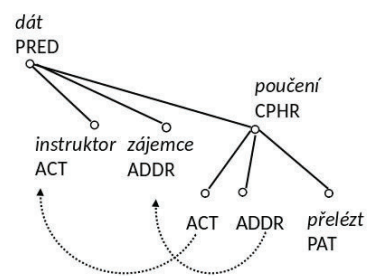

b.

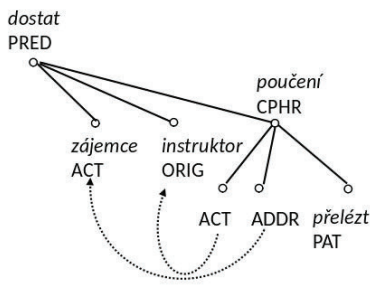

c.

Obrázek 2. Zjednodušené závislostní stromy vět (15c) (strom a. vlevo), (15d) (strom b. uprostřed) a (15e) (strom c. vpravo); koreference verbálních a nominálních valenčních doplnění je vyznačena šipkou směřující od povrchově nevyjádřeného valenčního doplnění $\mathrm{k}$ doplnění povrchově vyjádřenému

V př́padě, že verbální jména vyjadřující abstraktní výsledek děje selektují kategoriální sloveso, jehož valenční rámec je omezen na CPHR a nominativního ACT, např. mít pochopení v (17a), koreferuje sémanticky nenaplněný ACT slovesa s ACT jména, přičemž z koreferující dvojice je na povrchu v pozici subjektu vyjádřen verbální ACT jakožto obligatorní doplnění kategoriálního slovesa (princip 2.1, odd. 3). Př́padné další participanty jména se realizují na povrchu jako adnominální rozvití, přičemž při jejich vyjádření pozorujeme i nesystémové morfematické formy, typické pro verbální jména ve významu abstraktního výsledku děje (odd. 2.2), viz např. předložkovou skupinu pro+akuzativ vyjadřující PAT jména pochopení označujícího abstraktní výsledek děje v (16b) a (17a-b), která nemá oporu v rámci jeho základového slovesa pochopit $\mathrm{p}^{\mathrm{p}}(16 \mathrm{a})$.

(16) a. pochopit $t^{\mathrm{pp}}: \mathrm{ACT}_{1}{ }^{\text {obl }} \mathrm{PAT}_{4, \mathrm{zda} \text {,̌̌e,cont }}{ }^{\text {obl }}$

b. pochopení (abstraktní výsledek děje): $\mathrm{ACT}_{2, \mathrm{pos}, \mathrm{od}+2} \mathrm{PAT}_{\text {pro+4 }}$

(17) a. Někteří zaměstnavatelé ${ }_{\text {ACT-v-nom }}$ nemají pochopení ${ }_{\text {CPHR-v-acc }}$ pro matky $y_{\text {PAT-n-protacc }}$ s malými dětmi. (SYNv8)

b. Z těchto prožitků pak může pramenit také autorovo ${ }_{\mathrm{ACT}-\mathrm{n} \text {-pos }}$ pochopení pro jednání $\left.\right|_{\text {PAT-n-protacc }}$ venkovanů (SYNv8)

\subsubsection{Srovnání verbonominálních konstrukcí se jmény ve významu události a abstraktního výsledku děje v objektové pozici}

Z uvedených pozorování vyplývá, že u verbonominálních predikátů s kategoriálním slovesem, jejichž jádro tvoří verbální jméno s významem události v objektové pozici, kategoriální slovesa umožňují v povrchové struktuře vyjádřit participant korespondující s ACT jména, typicky Agens v širokém slova smyslu, a to jako subjekt, zatímco př́padné další participanty jména se typicky na povrchu 
realizují jako adnominální rozvití, vyjádřené systémovými formami (odd. 3.1.1). Kromě modifikace povahovodějových vlastností jména, které zde necháváme stranou, tak zapojení verbálního jména do verbonominálního predikátu umožňuje - v aktivní konstrukci - především zjednoznačnění původce děje, které kvůli pádové homonymii nebývá v nominálních konstrukcích vždy možné. Např. zatímco $\mathrm{v}(18 \mathrm{a})$ je přivlastňovacím adjektivem vyjádřen bud' ACT jména poučení (Teacher), nebo jeho ADDR (Student), v konstrukci s verbonominálním predikátem dochází $\mathrm{k}$ jejich desambiguaci, srov. dvě možné parafráze nominální konstrukce (18a) konstrukcemi s verbonominálním predikátem (18b-c).

(18) a. Petrovo ${ }_{\text {ACT/ADDR-n-pos }}$ poučení, jak poskytnout ${ }_{\mathrm{PAT}-\mathrm{n}-\mathrm{cont}}$ první pomoc

b. Petr ${ }_{\text {ACT-v-nom }}$ provedl poučení ${ }_{\text {CPHR-v-acc }}$ ostatních $_{\text {ADDR-n-gen' }}$

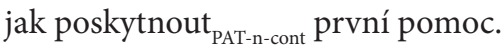

c. Někdo ${ }_{\text {ACT-v-nom }}$ provedl poučení $i_{\text {CPHR-v-acc }}$ Petra $_{\text {ADDR-n-gen' }}$

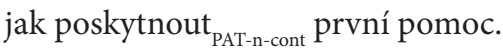

U verbonominálních predikátů, v nichž má verbální jméno význam abstraktního výsledku děje, přináší zapojení jména do verbonominální struktury variabilnější možnosti uplatnění participantů jména na povrchu a kategoriální sloveso v nich může sloužit jako prostředek hierarchizace větné struktury, jelikož výběrem různých kategoriálních sloves lze často do prominentní povrchověsyntaktické pozice subjektu umístit jiný participant jména, a tím situaci označovanou jménem perspektivizovat vždy z pohledu jiného jejího účastníka, srov. př́klady (15d) s (15e-f), uvedené výše v odd. 3.1.2, v nichž se v závislosti na kategoriálním slovese dostává do pozice subjektu bud' Teacher (15d), nebo Student (15e-f). Participanty jména vyjádřené jako adnominální rozvití mohou mít $\mathrm{v}$ těchto př́padech vedle systémových forem i formy nesystémové, které nemají oporu v rámci základového slovesa daného jména.

\subsection{Verbální jména v subjektové pozici}

\subsubsection{Význam události}

Verbální jména s významem události obsazují pozici subjektu např̀ u kategoriálních sloves konat se ${ }^{\mathrm{impf}}$, nastávat ${ }^{\mathrm{imp}} /$ nastat $^{\mathrm{pf}}$, probíhat ${ }^{\mathrm{imp} /} /$ proběhnout $^{\mathrm{pf}}$ a uskuteč-

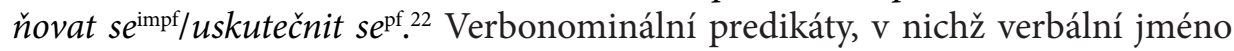

22 Souvýskyt těchto sloves $\mathrm{s}$ verbálními jmény byl ověřován $\mathrm{v}$ korpusu SYN2015 na základě dotazu [lemma="..."\&tag="V.*“], na jehož výsledek byl uplatněn pozitivní filtr $0,+1$ [tag="N...1.*“\&lemma=“.*ní|ti“], vyhledávající v nejbližším pravém kontextu slovesa jméno končící na -ní/-tí. Výsledek byl podroben manuální analýze, která ukázala, že tato slovesa vykazují vysokou míru souvýskytu s predikativními jmény ve významu události:v nejvyšší míře u slovesa probíhat (97 \%), v nejnižší míre u slovesa konat se (79\%). Srov. se slovesy se jménem v objektové pozici, odd. 3.1.1. 
daného typu obsazuje pozici subjektu, danou kategoriálním slovesem, skýtají limitované možnosti vyjádření nominálních sémantických participantů v povrchověsyntaktických pozicích slovesa, jelikož valenční rámce těchto kategoriálních sloves jsou často omezeny na jedinou nominativní valenční pozici CPHR, která je rezervována pro verbální jméno, viz např. valenční rámec slovesa nastat v (19b). Verbální jméno po obsazení této valenční pozice může své participanty na povrchu realizovat pouze jako doplnění jména, tedy stejně jako ve své nominální struktuře. Např. verbální jméno stýskání (si) s významem události se vyznačuje dvěma sémantickými participanty Experiencer a Content, které korespondují po řadě s ACT a PAT jména, viz valenční rámec jména v (19a). Selektuje-li toto jméno kategoriální sloveso nastat, obsazuje valenční pozici CPHR danou slovesem, a je tedy vyjádřeno v subjektu. Ve valenčním rámci slovesa nezbývá žádné další doplnění, a oba sémantické participanty jména tak mohou být v povrchové struktuře verbonominálního predikátu nastane stýskání vyjádřeny jako adnominální atributy, srov. verbonominální konstrukci (20a), jejiž syntaktickou strukturu zachycuje obr. 3a, a nominální konstrukci s daným jménem (20b).

Jelikož možnost uplatnění některého ze sémantických participantů jména $\mathrm{v}$ některé z povrchověsyntaktických pozic kategoriálního slovesa patř́i k definičním vlastnostem verbonominálních predikátů (viz odd. 3), vzniká otázka, zda existují syntaktické rysy, které dosvědčují, že i u těchto verbonominálních predikátů dochází k interakci mezi valenčním rámcem jména a slovesa. Domníváme se, že tuto interakci dokládají př́ípady, v nichž je sémantický participant korespondující s ACT jména vyjádřen jako volné doplnění místa LOC, které ač není součástí standardního valenčního rámce slovesa, náleží ke slovesu jako jeho fakultativní doplnění. Např. uplatní-li se verbální jméno dýchání s významem události v rámci verbonominálního predikátu dýchání probíhá, je možné jeho participant Agent korespondující s ACT jména, viz valenční rámec jména $\mathrm{v}$ (21a), povrchově strukturovat jako fakultativní LOC kategoriálního slovesa, tedy jako adverbiale místa (rámec slovesa $\mathrm{v}(21 \mathrm{~b})$ fakultativní volné doplnění v souladu s pravidly FGP nezachycuje); srov. verbonominální konstrukci (22a), zachycenou na obr. 3b, a nominální konstrukci (22b). Podobně viz též doklad verbonominálního predikátu zpomalení nastalo v př́kladu (24a) s kategoriálním slovesem nastat, viz valenční rámec slovesa $\mathrm{v}$ (19b), a verbálním jménem zpomalení, viz valenční rámec (23); $\mathrm{v}$ této konstrukci je jako fakultativní LOC v pozici adverbiale na povrchu vyjádřen sémantický participant jména Item, odpovídající ve valenčním rámci jména Konateli; srov. též povrchovou realizaci tohoto participantu ve verbonominální konstrukci (24a) a v nominální konstrukci (24b) ${ }^{23}$.

23 Podobné syntaktické chování lze předpokládat i u verbonominálních predikátů, jejichž součástí je kategoriální sloveso, které neotvírá pozici subjektu, srov. např. Kdy došlo

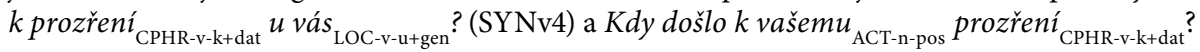


(19) a. stýskání (si) ${ }^{\mathrm{impf}}: \mathrm{ACT}_{2, \mathrm{pos}} \mathrm{PAT}_{\mathrm{po+6,že}}$

b. nastávat ${ }^{\mathrm{impf}} /$ nastat $^{\mathrm{p}}: \mathrm{CPHR}_{1}^{\mathrm{obl}}$

(20) a. Časem tedy nastane stýskání ${ }_{\mathrm{CPHR}-\mathrm{v}-\mathrm{nom}}[\text { obyvatel }]_{\mathrm{ACT}-\mathrm{n} \text {-gen }}$ po větším

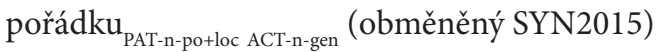

b. lze pozorovat stýskání obyvatel ${ }_{\mathrm{ACT} \text {-n-gen }}$ po větším pořádku $\mathrm{PAT}-\mathrm{n}$-po+loc

(21) a. dýchánímpf: $\mathrm{ACT}_{2, \mathrm{pos}} \mathrm{PAT}_{2}$

b. probíhat ${ }^{\mathrm{impf}} /$ proběhnout $\mathrm{pf}^{\mathrm{p}}: \mathrm{CPHR}_{1}^{\text {obl }}$

(22) a. Rovněž dýchání ${ }_{\text {CPHR-v-nom }}$ probíhá u lezců ${ }_{\text {LOC-v-u+gen }}$ originálním způsobem ${ }_{\text {ACT-n-gen }}$ (SYN2005)

b. studuje dýchání lezců ${ }_{\text {ACT-n-gen }}$

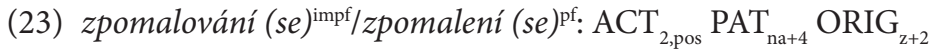

(24) a. Prudké zpomalení ${ }_{\text {CPHR-v-nom }}$ nastalo u růstu ${ }_{\text {LOC-v-u+gen }}$ spotřebitelských výdajů $_{\text {ACT-n-gen }} \quad($ SYNv8)

b. přednáška o zpomalení růstu ${ }_{\mathrm{ACT}-\mathrm{n} \text {-gen }}$ spotřebitelských cen

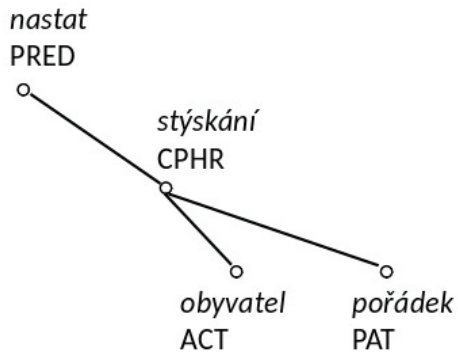

a.

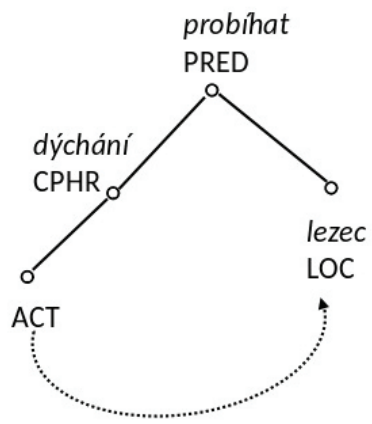

b.

Obrázek 3. Zjednodušené závislostní stromy vět (20a) (strom a. vlevo) a (22a) (strom b. vpravo); koreference verbálních a nominálních valenčních doplnění je vyznačena šipkou směřující od povrchově nevyjádřeného valenčního doplnění k doplnění povrchově vyjádřenému

\subsubsection{Význam abstraktního výsledku děje}

Verbální jména s významem abstraktního výsledku děje selektují kategoriální slovesa, která mohou mít ve svém valenčním rámci kromě valenční pozice vyhrazené pro jméno v nominativu i další valenční pozici (např. hlodat impf , jí$m a t^{\mathrm{impf}} / j_{m o u} \mathrm{p}^{\mathrm{pf}}$, lomcovat $^{\mathrm{impf}}$, obcházet $^{\mathrm{impf}} /$ obejít $^{\mathrm{pf}}$, opanovat ${ }^{\mathrm{pf}}$, ovládat $^{\mathrm{impf}} /$ ovládnout-

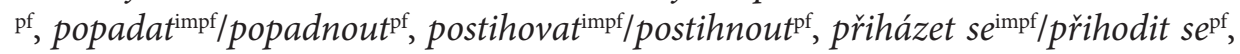


vjiždět $\left.t^{\mathrm{impf}} / v j e t^{\mathrm{pf}}, z m o c n ̌ o v a t ~ s e^{\mathrm{impf} / z m o c n i t} s^{\mathrm{pf}}\right)$. Tyto valenční pozice jako sémanticky nesaturovaná doplnění slovesa vstupují v rámci verbonominálních predikátů do koreference s valenčními doplněními jména, typicky se jmenným ACT, skrz něhož získávají sémantickou specifikaci. Často jde o PAT slovesa, vyjádřený $\mathrm{v}$ pozici prímého objektu, viz valenční rámec slovesa jímat $\mathrm{v}(25 \mathrm{~b})$, nebo $\mathrm{v}$ pozici neprímého objektu, viz valenční rámec slovesa lomcovat $\mathrm{v}(27 \mathrm{~b})$ a prihodit se $\mathrm{v}$ (29b), př́íp. se jedná o volné doplnění, realizované v pozici adverbiale, viz např. doplnění místa LOC ve valenčním rámci slovesa hlodat $\mathrm{v}(31 \mathrm{~b})$. Je-li dané slovesné doplnění obligatorní, vyjadřuje se na povrchu př́slušný sémantický participant jména, ke kterému dvojice koreferujících doplnění odkazuje, jako rozvití slovesa (princip 2.1, odd. 3), viz PAT sloves jímat a lomcovat v pŕíkladech (26a) a (28a) a LOC slovesa hlodat v př́kladu (32a), viz též obr. 4, reprezentující zjednodušené závislostní stromy vět (26a) a (32a). Pokud je dané doplnění slovesa fakultativní, viz PAT v rámci slovesa přihodit se (29b), je možné daný participant povrchově vyjádřit bud' jako rozvití slovesa (30a), nebo jako rozvití jména (30b) (princip 2.2, odd. 3); srov. též uvedené verbonominální konstrukce a nominální struktury $\mathrm{v}$ př́kladech (26b), (28b), (30c) a (32b), k nim viz též valenční rámce jmen (25a), (27a), (29a) a (31a).

(25) a. podezrení: $\mathrm{ACT}_{2, \mathrm{pos}} \mathrm{PAT}_{2, \text { na }+4,0+6, \text { zda,ž,cont }}$

b. jímat ${ }^{\text {impf }} / j m o u t^{\mathrm{pf}}: \mathrm{CPHR}_{1}^{\text {obl }} \mathrm{PAT}_{4}^{\text {obl }}$

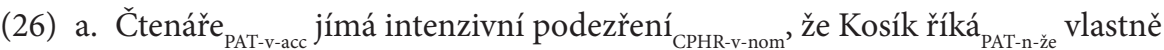
stále totéž. (SYN2000)

b. čtenářovo ${ }_{\mathrm{ACT}-\mathrm{n}-\mathrm{pos}}$ intenzivní podezření, že Kosík říká $\mathrm{PAT}_{\mathrm{PA}-\mathrm{n}-\mathrm{z} \mathrm{e}}$ vlastně stále totéž, je pochopitelné

(27) a. rozčilení: $\mathrm{ACT}_{2, \text { pos }} \mathrm{PAT}_{\text {nat4,nad }+7,2+2, \text { ž, cont }}$

b. lomcovat ${ }^{\text {imp: }} \mathrm{CPHR}_{1}^{\text {obl }} \mathrm{PAT}_{7, s+7}$ obl

(28) a. ČVK a Slavia vybojovaly nádherný boj, při němž rozčilení ${ }_{\text {CPHR-v-nom }}$ lomcovalo zástupy $_{\text {PAT-v-instr }}$ obecenstva. (SYNv4)

b. vnímal rozčilení zástupů ${ }_{\mathrm{ACT}-\text {-ngen }}$ obecenstva

(29) a. zraněni $i^{24}: \mathrm{ACT}_{2, \text { pos }}$

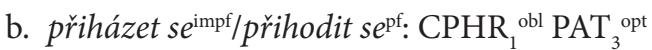

(30) a. Zranění ${ }_{\text {CPHR-v-nom }}$ se hokejistovi $i_{\text {PAT-v-dat }}$ přihodilo na stroji k posilování nohou. (SYN2006pub)

b. Hokejistovo ${ }_{\text {ACT-n-pos }}$ zranění ${ }_{\text {CPHR-v-nom }}$ se přihodilo na stroji k posilování nohou.

c. hokejistovo ${ }_{\mathrm{ACT}-\mathrm{n} \text {-pos }}$ zranění není vážné

${ }^{24}$ Jde o význam jména zranění, jehož základovým protějškem je sloveso zranit se. 
(31) a. tušení: $\mathrm{ACT}_{2, \text { pos }} \mathrm{PAT}_{2, \mathrm{že}, \text { cont }}$

b. hlodat ${ }^{\text {impf: }} \mathrm{CPHR}_{1}{ }^{\text {obl }} \mathrm{LOC}^{\text {obl }}$

(32) a. Přitom v kdekom ${ }_{\text {LOC-v-v+loc }}$ dávno hlodá zlé tušení ${ }_{C P H R-v-n o m}$, že česká společnost a její ekonomika spěje PAT-n-že $_{\mathrm{k}} \mathrm{k}$ maléru. (SYN2000)

b. nepřekvapovalo ho zlé tušení kdekoho ${ }_{\text {ACT-n-pos }}$ že česká společnost a její ekonomika spěje ${ }_{\text {PAT-n-že }} \mathrm{k}$ maléru

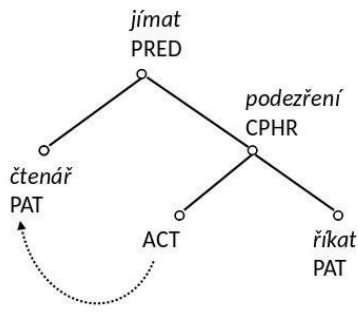

a.

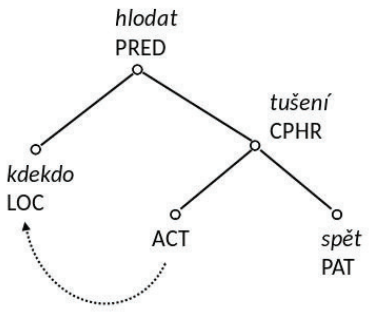

b.

Obrázek 4. Zjednodušené závislostní stromy vět (26a) (strom a. vlevo) a (32a) (strom b. vpravo); koreference verbálních a nominálních valenčních doplnění je vyznačena šipkou směřující od povrchově nevyjádřeného valenčního doplnění k doplnění povrchově vyjádřenému

\section{Závěr}

V příspěvku jsme porovnávaly valenční strukturu verbálních jmen ve významu události a abstraktního výsledku děje v nominálních a verbonominálních konstrukcích. Poukázaly jsme na skutečnost, že verbální jména daných dvou typů se z hlediska jejich uplatnění v těchto konstrukcích chovají odlišným způsobem: v obou případech se liší především v možnostech povrchové realizace svých doplnění. Povrchové vyjádření valenčních doplnění verbálních jmen ve významu události v nominálních strukturách lze odvodit z valenčních rámců jejich základových sloves. Ve verbonominálních konstrukcích se pak na povrchu jako rozvití slovesa systematicky uplatňuje jmenný participant s rolí Agens (v širokém slova smyslu), který odpovídá jmennému ACT, zatímco další případné participanty se typicky vyjadřují jako adnominální rozvití. V prrípadě verbálních jmen s významem abstraktního výsledku děje zjištujeme, že některé formy, určující povrchové vyjádření valenčních doplnění v nominálních konstrukcích, nelze odvodit $\mathrm{z}$ rámce jejich základových sloves. Ve verbonominálních konstrukcích pak verbální jména daného typu mohou často - kromě participantu korespondujícího se jmenným ACT - vyjádřit na povrchu jako rozvití slovesa i další sémantické participanty a výběr různých kategoriálních sloves jim často umožňuje perspektivizovat označovanou situaci pokaždé z hlediska jiného participantu. 


\section{Bibliografie}

Alonso Ramos, M. (2007). Towards the Synthesis of Support Verbs Constructions. In: L. Wanner (ed.), Selected Lexical and Grammatical Issues in the Meaning Text Theory (97-137). Amsterdam-Philadelphia: John Benjamins.

Apresjan, J. (2009). The Theory of Lexical Functions: An Update. In: D. Beck et al. (eds.), Proceedings of the fourth international conference on Meaning-Text Theory (1-14). Montreal: OLST.

Bosque, I. (2001). On the Weight of Light Predicates. In: J. Herschensohn et al. (eds.), Features and Interfaces in Romance: Essays in Honor of Heles Contreras (23-38). Amsterdam-Philadelphia: John Benjamins.

Butt, M. (2010). The Light Verb Jungle: Still Hacking Away. In: M. Amberber et al. (eds.), Complex Predicates: Cross-linguistic Perspectives on Event Structure (48-78). New York: Cambridge University Press.

Cattell, R. (1984). Composite Predicates in English. Sydney-New York-London: Academic Press.

Čermák, F. (2011). Jazyk a jazykověda. Přehled a slovníky. Praha: Karolinum.

Daneš, F. et al. (eds.). (1987). Mluvnice češtiny 3, Skladba. Praha: Academia.

Dvořák, V. (2016). Verbální substantivum. In: P. Karlík et al. (eds.), Nový encyklopedický slovník češtiny (1948-1953). Praha: Nakladatelství Lidové noviny.

Grimshaw, J., Mester, A. (1988). Light Verbs and $\theta$-Marking, Linguistic Inquiry, 19, 205-232.

Gross, M. (1981). Les bases empiriques de la notion de prédicat sémantique, Langages, 63, $7-52$.

Jespersen, O. (1965). A Modern English Grammar on Historical Principles, Part VI, Morphology. London: Allen and Unwin.

Jezek, E. (2011). Verbes supports et composition sémantique, Cahiers de Lexicologie, 98, 29-43.

Karlík, P. (2019). Škála nominalizací. In: P. Malčík, P. Karlík (eds.), Svět podle Grepla (91-110). Brno: Host.

Kettnerová, V. et al. (2018). Enriching VALLEX with Light Verbs: From Theory to Data and Back Again, The Prague Bulletin of Mathematical Linguistics, 111, 29-56.

Kolářová, V. et al. (2020). NomVallex I. Valenční slovník substantiv. Praha: Ústav formální a aplikované lingvistiky.

Křen, M. et al. (2019). Korpus SYN, verze 8 z 12.12.2019. Ústav Českého národního korpusu FF UK. http://www.korpus.cz/.

Lopatková, M. et al. (2016). Valenční slovník českých sloves VALLEX. Praha: Karolinum.

Macháčková, E. (1979). Analytické konstrukce typu sloves + abstraktní substantivum (Analytické vyjadřování predikátů) (nepublikovaná disertační práce). Praha: ÜJČ ČSAV.

Macháčková, E. (1983). Analytické predikáty. Substantivní názvy dějů a statických situací ve spojení s funkčními slovesy, Jazykovědné aktuality, 10, 122-176. 
Panevová, J. (1980). Formy a funkce ve stavbě české věty. Praha: Academia.

Panevová, J. (2002). K valenci substantiv (s ohledem na jejich derivaci), Zbornik Matice srpske za slavistiku, 29-36.

Panevová, J. et al. (2014). Mluvnice současné češtiny 2, Syntax na základě anotovaného korpusu. Praha: Karolinum.

Radimský, J. (2010). Verbonominální predikát s kategoriálním slovesem. Praha: Karolinum.

Radimský, J. (2017). Analytický predikát s kategoriálním slovesem. In: P. Karlík et al. (eds.), CzechEncy - Nový encyklopedický slovník češtiny. https://www.czechency. org/slovnik/ANALYTICK\%C3\%9D\%20PREDIK\%C3\%81T\%20S\%20KATEGORI\%C3\%81LN\%C3\%8DM\%20SLOVESEM

Urešová, Z. (2019). SynSemClass 1.0. Praha: Institute of Formal and Applied Linguistics, LINDAT/CLARIN Research Infrastructure 2019. https://ufal.mff.cuni.cz/ synsemclass

Veselovská, L. (2001). K analýze českých deverbálních substantiv. In: Z. Hladká, P. Karlík (eds.), Čeština - univerzália a specifika 3 (11-27). Brno: Vydavatelství MU.

ABSTRAKT: Česká verbální jména (zakončená sufixy -ní/-tî) označující událost (např. poučení jako proces) nebo abstraktní výsledek děje (např. poučení jako předaná informace) se $\mathrm{z}$ hlediska valence liší především tím, jak v povrchové struktuře vyjadřují svá valenční doplnění. V nominálních konstrukcích je povrchové vyjádření valenčních doplnění verbálních jmen označujících událost odvoditelné z valenční struktury jejich základových sloves. Oproti tomu verbální substantiva označující abstraktní výsledek děje užívají k povrchovému vyjádření svých valenčních doplnění vedle systémových morfematických forem i formy nesystémové. Ve verbonominálních konstrukcích, v nichž je syntaktickým centrem kategoriální sloveso, verbální jména označující událost systematicky uplatňují na povrchu jako subjekt slovesa participant Agens (v širokém slova smyslu). Oproti tomu verbální jména označující abstraktní výsledek děje mohou často na povrchu jako rozvití slovesa vyjádřit i své další sémantické participanty a výběr různých kategoriálních sloves jim často umožňuje perspektivizovat označovanou situaci pokaždé z hlediska jiného participantu.

\section{WALENCJA CZESKICH RZECZOWNIKÓW ODCZASOWNIKOWYCH W KONSTRUKCJACH NOMINALNYCH I W WERBO-NOMINALNYCH PREDYKATACH Z CZASOWNIKIEM KATEGORIALNYM}

ABSTRAKT: Czeskie rzeczowniki odczasownikowe (kończące się na przyrostek -ní/-tí) oznaczające zdarzenie (np. poučení jako proces) lub abstrakcyjny rezultat akcji 
(np. poučení jako przekazana informacja) różnią się z punktu widzenia walencji głównie tym, jak wyrażają swoje dopełnienia walencyjne w strukturze powierzchniowej. W konstrukcjach nominalnych wyraz powierzchniowy dopełnien walencyjnych rzeczowników odczasownikowych oznaczających zdarzenie można wyprowadzić ze struktury walencyjnej ich bazowych czasowników. Natomiast rzeczowniki odczasownikowe oznaczające abstrakcyjny rezultat akcji po to, aby powierzchownie wyrazić swoje dopełnienia walencyjne, używają oprócz systemowych form morfematycznych również formy niesystemowe. W konstrukcjach werbo-nominalnych, w których centrum syntaktycznym jest czasownik kategorialny, rzeczowniki odsłowne oznaczające zdarzenie systematycznie wymagają na powierzchni jako partycypanta czasownika Agensa (w szerokim znaczeniu). Z kolei rzeczowniki odczasownikowe oznaczające abstrakcyjny rezultat akcji często mogą na powierzchni wyrażać innych uczestników semantycznych jako uzupełnienie czasownika, a wybór różnych czasowników kategorialnych często pozwala im za każdym razem spojrzeć na wskazaną sytuację z punktu widzenia innego uczestnika. 